\title{
Kiss of life for Clinch River breeder
}

Reagan ditches

Carter policy

\section{on proliferation}

\section{Washington}

Despite the objections of his economic advisers, President Ronald Reagan has decided to pay off some of his political debts by letting construction work begin on the liquid metal fast-breeder reactor at Clinch River in Tennessee, which critics claim is both economically unnecessary and technically out of date. However, $\mathrm{Mr}$ Reagan is holding back from providing further federal support for the reprocessing of spent nuclear fuel until it becomes clear whether the private sector is prepared to take on this reponsibility.

Both the fast breeder programme and commercial spent-fuel reprocessing had been held in check by President Carter on the grounds that they contributed to the growth of the "plutonium economy" and thus raised the risk of the proliferation of nuclear weapons. But both decisions have come under strong attack from the nuclear industry as an unnecessary restriction on the growth of nuclear power, an attitude known to be held by the new Energy Secretary.

In his budget request to Congress, the full details of which were released last week, President Reagan is requesting a total of $\$ 737$ million for support of fastbreeder research in the fiscal year 1982. A substantial proportion of this increase will go towards the start of construction work on the Clinch River reactor as a "demonstration project"'. Development funds have already paid for the design and much of the component fabrication, but construction had previously been held up by President Carter's request to the Nuclear Regulatory Commission not to issue a construction licence.

The Clinch River reactor has a high symbolic value for the US nuclear industry. Many used it to focus their opposition to $\mathrm{Mr}$ Carter's general non-proliferation policies. Others argued against the Carter Administration's conclusion that the declining rate of increase in the demand for electricity, and a short-term surplus in domestic uranium supplies, reduced the need for an intensive breeder development programme.

Environmentalists now point out that they have a new - and perhaps surprising - ally, Mr David Stockman, director of the Office of Management and Budget and the chief architect of Mr Reagan's austerity budget. Using the same arguments put forward by the Carter Administration, $\mathrm{Mr}$ Stockman circulated a letter to fellow con-

gressmen in 1977 describing plans to subsidize the construction of the Clinch River reactor as "totally incompatible with the free market approach to energy policy".

Critics of fast-breeder reactors, such as the Natural Resources Defense Council, claim that in order to find the money for increased spending on nuclear programmes in general, including the liquid metal fastbreeder reactor, the Department of Energy is intending to cut back significantly in research and development on alternative energy sources. It is proposed to cut the solar energy research budget, for example, from \$625 million in 1981 to \$241 million in 1982 , and research and development in conservation from $\$ 558$ to $\$ 195$ million, while research on fission reactors would increase from $\$ 1,166$ to $\$ 1,247$ million.

Even the Office of Management and Budget is said to have argued that there is

\section{British academics up in arms}

British universities were in a state of shock last week after the government's announcement of its spending plans for the next three years. Spending on home students is to be cut by 8 per cent in real terms by 1983-84. The Committee of ViceChancellors and Principals estimates that the total reduction in university income could be as high as 15 per cent when the shortfall in overseas students, expected after the government's decision to charge them economic fees, is taken into account. Sir Alec Merrison, chairman of the Committee of Vice-Chancellors, last week described the expenditure plan as madness. $\mathrm{He}$ said he was not aware that the government was reducing the universities' grant for any reason other than saving public money.

The cuts will undoubtedly force the universities to review the services they can offer, which is a fact acknowledged by the government in its white paper on expenditure published on budget day, 10 March. The vice-chancellors and the University Grants Committee seem to have persuaded the Secretary of State for Education that money should be set aside for the scaling down operation. But, instead of making more money available, as the universities must have hoped, the government announced on 13 March that $£ 20$ million should be taken out of the 1981-82 recurrent grant - at $£ 979$ million already 3 per cent less than for 1980-81 for the purpose.

The Committee of Vice-Chancellors estimates that making necessary economies could be more expensive than maintaining the universities at their present level. The problem is that after several years of static budgets, further economies cannot be made without reducing staff. Salaries and related costs at present consume 72 per cent of the recurrent grant, more than half of an inconsistency in cutting off support for "demonstration" projects in solar and fossil energy, while supporting just such an approach for fast breeders; Mr Stockman is said to have put up a fierce battle against Clinch River funding, although he was less opposed to the increased budget request for design work on a larger, more advanced fast breeder.

In a report published by the subcommittee last week, a former member who left Congress last autumn, Republican congressman John Wydler of New York, reported on a visit to the British fast breeder programme, and used the British (and French) experience to bolster his argument that completion of Clinch River is the logical next step for the United States.

Mr Wydler also reported that British scientists were attracted to the idea of cooperation with the United States, a move

that going on academic pay. Redundancies, which would break the contracts of employment of tenured academics (approximately 80 per cent hold tenure), would involve the universities in costly litigation and large redundancy payments. And the committee's estimate that one in eight jobs will have to go would certainly mean the closure of departments and possibly entire universities. Nobody yet knows whether the $£ 20$ million set aside will be enough to help meet these costs.

The University Grants Committee will begin dividing what money there is between institutions in May. It is not thought to

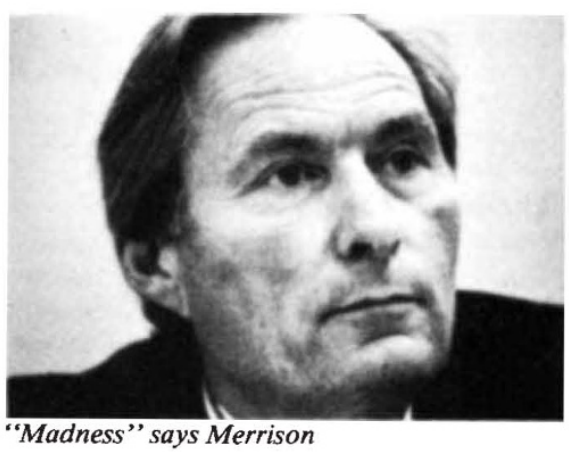

favour cutting any university's grant completely, but neither does it want to spread the money too thinly. Possible alternatives are to close selected departments - a new move for the committee, which normally leaves individual universities to run their own affairs - or to restructure the system, leaving some universities to develop as centres of excellence and turning others into something akin to American liberal arts colleges. The trouble is that the committee has never had to be so dirigiste in the past and has not formed a proper mechanism to take the necessary decisions.

Judy Redfearn 